\section{Squatter Settlements and Slums and Sustainable Development}

\author{
Manoranjan Mohanty \\ The University of the South Pacific, Suva, Fiji
}

\section{Synonyms}

Informal settlements

\section{Definition}

Squatter settlement is defined as a low residential area, which has developed without legal right to the land or permission from the concerned authorities to build, and as a result, of their illegal status, infrastructure and services are usually inadequate (UN-Habitat 2003). On the other hand, slums are contiguous settlements where inhabitants are characterized by insecure residential status, inadequate access to safe water, inadequate access to sanitation and other basic infrastructure and services, poor housing quality, and overcrowding (UN-Habitat 2003). Both are form of informal settlements that are not formally planned.

\section{Introduction}

In this entry, the squatter settlements and slums are discussed critically. At the outset, the concepts of squatter settlement and slum are defined, and the meaning, processes, causes, consequences, and challenges of squatter settlements and slums are discussed. There have been rapid urbanization and unbalanced growth of cities with many physical, social, economic, and environmental consequences. One of the adverse effects of "unintended urbanization" is marginalization of social groups and growth of squatter settlements and slums. Squatter settlements and slums are challenges to sustainable urban planning and urban development. Sustainable Development Goal 11 focuses on the theme "Sustainable Cities and Communities" under the heading "Make cities and human settlements inclusive, safe, resilient and sustainable" (United Nations 2013).

In terms of content arrangement, the main text is organized into eight sections. Section "Introduction" provides an introduction of the paper. Section "Informal Urbanization and Urban Informality" focuses on the informal urbanization and urban informality. Section "Informal Settlements: Characteristics of Squatter Settlements and Slums" deals with informal 
settlements and the basic characteristics of squatter settlements and slums. Section "Theorizing Squatter Settlements and Slums" discusses the concept of squatter settlement and slum and the discourse. Section "Urban Policies and Planning for Squatter Settlements and Slums" focuses on the urban policies and planning for squatter settlements and slums and covering slum improvement or upgrading and the challenges of squatter settlements and slums and slum upgrading. Section "Squatter Settlements and Slums and Sustainable Development" covers squatter settlements and slums and sustainable development. Section "Way Forward" provides a way forward, and the last section is the conclusion.

\section{Informal Urbanization and Urban Informality}

Informal urbanization refers to informal, unregulated, and spontaneous processes of urbanization especially in the cities of Global South and is the resulting effect of marginalization of social groups, poverty, and inequality (Mohanty 2019). It is that part of urban population, which is deprived of basic amenities and services in a city. It is the impoverished neighborhoods within a city or town. Informal urbanization emerges because of inability of cities to absorb growth within formal urban framework due to absence of serviced land and affordable housing, inadequate urban planning regulations, and exclusion of low-income populations from formal urbanization (Mohanty 2019). Informal urbanization process includes both poor rural migrants who builds their home through gradual processes of informal land occupation and consolidation and developer who subdivides land without complying with urban regulations (Roy 2005). In the Global South, informal urbanization is symptom of "urbanization of poverty," i.e., rising share of poor living in urban areas (Ravallion et al. 2007).

Informality is a defining characteristic of urbanization and urban life in the developing countries. The importance of informality in processes of urbanization is widely acknowledged (Bunnel and Harris 2012; Bellegooijen and
Rocco 2013; Rocco and Bellegooijen 2018). Urban squatter settlements and slums are closely associated with the concept of urban informality, which is a key component of informal urbanization. Dovey and King (2011) noted that "informality" implies a lack of formal control over planning, design, and construction. Hernando De Soto (1989) in his book, The Other Path, argues that informality causes poverty, as it is a factor of exclusion from the formal market. Informal urbanizations and informal settlements have various scholarly descriptions such as "shanty towns" (Beard 1920), "planet of slums" (Davis 2006), "billion squatter population" (Neuwirth 2004), and "dysfunctional urban societies" (UN-Habitat 2006), and these narratives have deep entrenched socio-spatial inequalities (Lombard 2014).

\section{Informal Settlements: Characteristics of Squatter Settlements and Slums}

The housing and shelter needs of low-income families, which are not being met in formal sector, have expanded marginalization and informal settlements. Globally, over one billion residents reside in urban informal settlements (World Bank 2015). Surveys indicate that between $40 \%$ and $70 \%$ of urban dwellers in developing countries live in squatter settlements and slums and the trend does not show any sign of slowing down (UN-Habitat 2003). Informal settlements include squatter settlements and slums that are selfconstructed entities within cities and towns and the resulting effect of informal urbanization (Mohanty 2019). Informal settlements especially squatter settlements are areas that are not formally planned, nevertheless, occupied illegally by the dwellers. The UN-Habitat (2003) defined informal settlements as (i) residential areas where a group of housing units has been constructed on land to which the occupants have no legal claim or which they occupy illegally and (ii) unplanned settlements and areas where housing is not in compliance with current planning and building regulations. Informal settlements thus have a complex continuum of both legality and illegality where squatter settlements formed through land 
invasion and self-help housing can exist alongside informal subdivisions formed through legal ownership and market transaction but in violation of land use regulations (Roy 2005).

The growth of informal settlements is spontaneous response to the rapid urbanization. An unprecedented rate of urbanization and increasing poverty has resulted in uncontrolled proliferation of squatter settlements and slums. Informal settlements result in undesirable urbanization driven less by economic growth and more by rural-urban migration of the poor. The growth of urban informal settlements is caused by physical, socioeconomic, cultural, institutional, political, and historical factors. The physical factors are concerned with the nature of the land on which people build unauthorized structures. Example of such lands includes marginal or less valuable urban lands that are environmentally most vulnerable such as land along river valleys, steep slopes, dumping grounds, abandoned or unexploited plots, land along transportation networks, near industrial areas, and low-lying areas and wetlands (Global Urban Observatory 2003).

The informal settlements are known as unauthorized, unplanned, uncontrolled, marginal, or spontaneous settlement and a resulting effect of spontaneous informal urbanization. They are also referred as "auto settlement," "abnormal" and "dysfunctional settlement," "unjust settlement," and, simply, shack (Mohanty 2019). Squatter settlements and slums are common in developing countries, and the slum formation produces a variety of local settlement types (Acioly 2007). These settlements acquire different names in different countries, e.g., "favelas" in Brazil, "basti" and "Zopadpatti" in India, "ranchos" in Venezuela, "villas miseria" in Argentina, "katchi abadis" in Pakistan, "bariadas" in Peru, and "squatter camp" in South Africa. The slums and squatter settlements are, however, not uncommon in developed world. They are known as, e.g., "Baraccopalli" in Italy, "Chabolas" in Spain, "Bidonvilles" in France, and "Mahalale" in Romania. Regardless of their various names or types, the squatter settlements and slums have common characteristics, being residential areas of low-income group dwellings in the cities and towns. They are characterized by a lack of most or all of the basic urban services like infrastructural, welfare, and community services. They lack the basic municipal services, such as water supply, sanitation, waste collection, or infrastructure, and are exposed to diseases, crimes, and natural disasters. The UN-Habitat (2003) reported the main characteristics of slums are inadequate access to safe water, inadequate access to sanitation and other infrastructure, overcrowding and insecure residential status, and poor quality of housing. Slum housing is often supplied illegally on the informal market, and there exist many types of ownership relationships between different actors. Some are self-built houses, some are occupied houses, but often, the houses are for rent from informal landlords (UN-Habitat 2003). Amis (1984) in a study in Nairobi found commercialization of unauthorized low-income housing involving landlords and tenants.

Srinivas (2015) identified three defining characteristics of squatter settlements: physical, social, and legal. In terms of physical characteristics, a squatter settlement, due to its inherent "non-legal" status, has services and infrastructure below the "adequate" or minimum levels (ibid.). In terms of social characteristics, most of the squatter settlement households belong to the lower-income group, working either as wage laborer or in various informal sector enterprises (Srinivas 2015; Mohanty 2006). The key characteristic that differentiates a squatter settlement is its lack of ownership of the land on which they build their house (Srinivas 2015). Amis (1984) noted the characteristics of squatter settlement as illegality and informality, low residential space, unauthorized housing and temporary dwellings, inappropriate locations, overcrowding, restricted public utilities and urban basic services, poverty and vulnerability, social stress and poor health, informal economic activities, and environmental hazards and degradation. Infrastructural deficits; social deprivation and stigmatization; institutional dimension such as lack of security tenure, isolation, and exclusion from social interaction; and economic opportunities, unhealthier environment, 
high unemployment, and low educational level among the dwellers are the other defining characteristics of squatter settlements and slums.

\section{Theorizing Squatter Settlements and Slums}

The terms squatter settlement and slum are used interchangeably; however, they differ significantly. An operational definition of slum adopted by the United Nations in Nairobi in 2002 was restricted to the physical and legal characteristics of the settlement (UN-Habitat 2003). The UN-Habitat (2003) defined slum as contiguous settlements where inhabitants are characterized by (i) insecure residential status, (ii) inadequate access to safe water, (iii) inadequate access to sanitation and other basic infrastructure, (iv) poor structural quality of housing, and (v) overcrowding. Slums are areas with high social exclusion and poverty (UN-Habitat 2010). On the other hand, squatter settlement is defined as a low residential area, which has developed without legal right to the land or permission from the concerned authorities to build; as a result of their illegal status, infrastructure and services are usually inadequate (UNHabitat 2003; Srinivas 2015). It means slums are areas where people with land ownership live in poor environmental and socioeconomic conditions and are different from squatter settlements, which are the settlements where people build houses without any legal title to land (UN-Habitat 2003). Slums in cities are commonly referred as "shanty towns," i.e., a settlement of improvised housing, which is called "shanties" or "shacks" (Beard 1920) and made of plywood, corrugated metal, plastic sheets, and cardboard boxes. They are also termed as "shadow cities" (Neuwirth 2004). A typical slum or "shantytown" often lacks adequate infrastructure, including proper sanitation, safe water supply, electricity, streets, or other necessities to support human settlements. As opposed to slums, squatter settlements are transitional or temporary in nature that lack land tenure. A squatter settlement can include both a slum and a squatting. Squatting is the action of squatter illegally occupying an abandoned or vacant land or building, usually residential. A "squatter" is a person who takes unauthorized possession of unoccupied premises, and they "squat" on vacant land, either private or public (Srinivas 2015). Pruijt (2011) suggested five distinct types of "squatting" such as:

(a) Deprivation-based squatting - involves poor homeless people who are distressed for their housing need.

(b) Alternative housing strategy - people organize squatting to meet their housing needs.

(c) Entrepreneurial squatting - offers opportunities any kind of establishment without much resources.

(d) Conservational squatting - a tactic used in the preservation of a cityscape or landscape against efficiency-driven planned transformation.

(e) Political squatting - a field of action for those who are engaged in anti-systemic politics.

According to Srinivas (2015), the term "squatter settlement" is a more recent western-initiated development, which captured in the earliest writings of authors such as Abrams (1964), John Turner (1969), and Pyne (1977). Abrams (1964) narrates the process of squatting as a "conquest" of city areas in search of a shelter. Turner (1969) portrays squatter settlements as highly successful solutions to housing problems in urban areas of developing countries. Pyne (1977) depicts the development of squatter settlements in the overall perspective of urban growth in the Third World.

The term "slum" was originally referred to the overcrowded, squalid inner-city tenements of industrializing cities in Europe in North America (Ward 1976). More recently, it has been resurrected by UN-Habitat in its global "Cities Without Slums" campaign to refer to any urban area that suffers from one or more of the following conditions: nondurable structures (e.g., shacks), insufficient living area (i.e., overcrowding), deficient access to adequate water facilities, or deficient access to adequate sanitation facilities (UNHabitat 2008). 
Slums are considered a by-product of modernization, economic growth, and the processes of industrialization and urbanization (Fox 2013). Frankenhoff (1967) suggested that "slums necessarily belong to the process of economic growth in a developing country" by acting as "the staging area for the migrating poor" as they work to integrate themselves into the economic life of cities in expanding economies. Turner (1969) argued that slums and squatter settlements are "both the product of and the vehicle for activities which are essential in the process of modernization." According to this perspective, poor rural migrants initially cannot afford to build, buy, or rent decent housing and opt instead for cheap, substandard units close to employment opportunities (Fox 2013). In other words, modernization theory portrays slums as a natural and temporary manifestation of a market failure arising from the dynamics of structural change in labor markets (ibid.). Fox (2013) noted this teleological theory is premised on several flawed assumptions. First, it assumes that slum settlements grow to accommodate labor migrants. Second, it assumes that economic growth will trickle down to those living in slums, allowing them to improve their lot. Third, it assumes that slums provide cheap housing for cheap labor, but the costs of living vary widely.

A number of theories explain the deviation from the assumed path of modernization, and they portray the persistence of slums as a manifestation of land and housing market failures arising from demographic, economic, or institutional factors (Fox 2013). However, the most popular explanation for the growth of slums and squatter settlements is rapid urbanization especially in developing countries. Obudho and Mhlanga (1988) observed that "the development of slum and squatter settlements in Africa is a direct manifestation of the high rate of urbanization."

Turok and Borel-Saladin (2016) provided two contrasting perspectives on the role of informal settlements in urban markets. Firstly, they help to lift households out of poverty and on to prosperity through affordable access to urban opportunities. Secondly, the deliberating conditions confine residents to enduring hardship and insecurity. Squatter settlement households continue in "poverty traps" (Bowles et al. 2011). The "urbanization of poverty" continues in cities as a continuous struggle of a growing number of poor for land, housing, and livelihoods in an urban environment (Evans 2002). A "culture of poverty" does exist, and the urban poor migrants and squatter dwellers become deeply entrenched in politics in cities, what Perlman (1976) explains in his work, The Myth of Marginality.

There are two approaches to slums that coexist as (a) slum of despair and (b) slum of hope (Eckstein 1990). Slum of despair describes the unbearable conditions people are forced to live in, the problem for people living in slums, and the problems the areas generate in society. Slum of hope, on the other hand, describes slum as providing housing solutions on a large scale to persons with low income and to the immigrants. They are places of dwelling for labor forces in the cities and sometimes places for formal and informal entrepreneurs (UN-Habitat 2003). Slum areas are also known as multicultural places with a rich artistic and cultural life (ibid.). They are significant economic forces. A large proportion of population in squatter settlements is in the informal sector employment, contributing to goods and services.

\section{Urban Policies and Planning for Squatter Settlements and Slums}

Slums are often portrayed as institutional failures in housing policy, housing finance, public utilities, local governance, and secure tenure (Sietchiping 2005). In the 1950s and the 1960s, the issue of slum in developing countries emerged as an important area of urban research and policies (Pugh 1997). Sietchiping (2005) discussed the governmental responses and policies toward slums under three approaches such as centralized control of housing, neo-liberal approach, and the preventive approach. He discussed this in a chronological sequence from the 1950 s as:

(a) Laissez-faire attitudes in the 1950s and 1960s - urban authorities considered slums as "relics of traditional villages" and mainly focused to 
public housing rather than slums. The policy makers and urban planners regarded the existing slums as temporary situation and as a minor threat to long-term development.

(b) Site and service programs in the $1970 \mathrm{~s}-$ most governments in developing countries opted for a direct and centralized (state) intervention, executed through World Bank's integrated programs such as the site and service scheme.

(c) Slum upgrading in the $1980 \mathrm{~s}$ - when the upgrading strategies emphasized the improvement of communal infrastructure and services within the slums. The upgrading program aimed to achieve three main goals such as affordability, cost recovery, and replicability.

(d) Enabling strategies and security tenure in the 1990s - the urban planning strategies were the development of practical mechanisms to consolidate and secure land tenure closely associated with World Bank's "enabling approach."

(e) Cities Without Slums action plan in the 2000s - the World Bank and the UN-Habitat initiated the Cities Without Slums (CWS) action plan in 1999 that aimed at improving the living conditions of at least 100 million slum dwellers by the year 2020 (UN-Habitat 2003).

According to Cockburn (2014), there are four approaches to urban planning of squatter settlements and slums. These are progressive development, security tenure and property rights, urban improvement or urban upgrading, and participation and community development. The progressive development approach to urban planning of John Turner (1969) and others opposing traditional urbanism led to policies during the $1960 \mathrm{~s}$ and 1970s that emerged promoting squatter settlement demolition ("bulldozer operations") with public housing and rural development establishing "self-help," sites and services, and upgrading of unplanned settlements (Carroll 2002; Green 2010 cited in Cockburn 2014). The progressive development approach argued that "residents of squatter settlements constitute poor families with unstable incomes who are seeking permanence in their housing, security of tenure (land), and shelter" (Cockburn 2014). Self-help construction of the home implies that family acts as its own contractor and enables a person "not only to build their home but to build their life" (ibid.). Sites and services programs were promoted in the 1970s.

The approach to security tenure (and legal ownership) and property right considered that the residents of informal settlements, before initiating the construction of their houses and installing services, require warranty on the part of state that they will not be evicted. The development and community participation approach developed in Latin American squatter settlements (ibid.). The fundamental concept of the development and community participation approach is that in informal settlements, "there is huge potential establishment of right to citizenship, based on community development" (Cockburn 2014). As a result, the informality can attain formality. The participatory approach and community development promotes horizontal participation as well. The urban upgrading is an integral improvement approach aiming to integrate squatter settlements into urban and social fabric of the formal city by promoting physical interventions articulated with social programs (ibid.).

\section{Squatter Settlements and Slum Upgrading}

Slum upgrading, improvement, or regularization is an integrated component of urban upgrading. Slum upgrading is a "process through which informal areas are gradually improved, formalised and incorporated into the city itself, through extending land, services and citizenship to slum dwellers" (Cities Alliance 2016). Slum upgrading aims to improve the areas and give dwellers what they lack in basic services, economic resources, and social support, and many projects work with legalization of informal households (Cities Alliance 2016). However, eviction of slum dwellers was common during the 1970s and the 1980s. In the late 1970s, slums began to be seen as a part of the solutions than problems. There was a marked shift in emphasis from policies that sought to eradicate squatter settlements or to relocate them to urban peripheries to urban upgrading strategies and providing services on site. Various 
urban development strategies have been adopted for squatter settlements that range from denial, tolerance, formalization, demolition, eviction, and displacement. It has been argued that poverty and inequality cannot be simply eradicated through demolition or eviction. There was an increasing focus on providing basic urban services, secure tenure, and the needs of the dwellers and the communities (UN-Habitat 2003). Many cities adopt alternatives that formalize these areas through incremental and on-site upgrading. Squatter settlement or slum upgrading is a process through which informal areas are gradually improved, formalized, and incorporated into the city itself, through extension of land and services to the dwellers. It provides squatter dwellers with the social, economic, institutional, and community services in the cities. These services may include legal (land tenure), physical (infrastructure), social (e.g., education or health), or economic services. The upgrading activities also include the provision of basic services such as housing, streets, footpaths, drainage, clean water, sanitation, and sewage disposal and access to education and health care.

Several authors analyzed approaches and methods of informal settlement upgrading (Pamuk and Cavallieri 1998; Abbott 2002; Amao 2012; Hermanson 2016). Two broad approaches as Amao (2012) noted have been used in urban upgrading of informal settlements: (1) community participation approach and (2) government intervention approach. The rationale behind community participation approach is that the communities know their needs better and should be consulted and carried along in the decision-making process (Amao 2012). The participation of the community in improving the quality of their settlement is also an important resource that has to be mobilized for improvement. Land sharing is an approach, which has brought about considerable settlement improvement by the initiative of the people themselves (Amao 2012). On the other hand, the approaches used by the public authorities have been settlement upgrading and "sites and services" (Amao 2012). Settlement upgrading has been an option where the landowner has reached a compromise and on a sharing basis; the squatter has been allowed to continue on the land parcel, but with a significant upgrading of the settlement's infrastructure and services. Where such land compromises or sharing has not been possible, the squatters have been relocated to another location, where varying levels of "sites" and "services" have been provided, with again land lease or ownership (Amao 2012).

The common methods adopted in informal settlements or slum upgrading are:

(a) Self-help housing: Self-help housing (Skinner and Rodell 1983) emerged in the 1970s. John Turner advocated slum improvements free of government intervention to allow their residents to change their living conditions by themselves (Werlin 1999). Self-help housing offers several advantages that include mobilization and realization of local social capital, greater ownership and control of the housing process by local residents, greater participation by residents in the design, and potentially the achievement of more valuable housing product as a result of equity and/or a more cost-effective construction process (Amao 2012).

(b) Relocations: Relocations may affect only a portion of the settlement or the entire settlement and may be temporary or permanent. The relocation of entire settlements to worse located land relative to livelihood opportunities and other amenities should be undertaken as a last resort (Amao 2012).

(c) In situ slum upgrading: it is an affordable, flexible, and viable option. According to Amao (2012), in situ or on-site upgrading is of two types: conventional in situ upgrading and nonconventional in situ upgrading. (i) Conventional in situ upgrading entails the redevelopment of an informal settlement in a comprehensive and relatively complete fashion in respect of housing, tenure, and infrastructural services (Amao 2012). (ii) Nonconventional in situ upgrading has become one of the most promising approaches to the housing crisis in the "Global South" (Ehebrecht 2015). This approach received 
an increasing attention, given the significant constraints in achieving conventional upgrading. Nonconventional upgrading as Ehebrecht (2015) noted takes two main forms: (a) the provision of interim relief measures and/or the initiation of initial upgrading measures to address key needs such as fire protection, basic sanitation, access to potable water, solid waste removal, basic health care, and improved internal access ways and (b) the delivery of a full upgrade solution but utilizing different methods and housing typologies.

\section{Challenges of Squatter Settlements and Slums and Upgrading}

Squatter settlements and slums are widespread phenomena that pose serious social, economic, cultural, political, and environmental challenges (Huchzermeyer and Karam 2007; Porter 2011; Hernandez et al. 2012). Among various social challenges, drug addiction, alcoholism, prostitutions, and criminal activities are perpetual problems in the squatter settlements and slums. High incidence of HIV/AID and prevalence of diseases including communicable diseases in these settlements are the perennial problems. Poor housing and living conditions, poor health-care options, low standard of living, lack of adequate water supply and sanitation, and poor urban basic services are the challenges. In terms of environmental challenges in the squatter settlements and slums, air and water pollution, lack of personal hygiene and poor environmental sanitation, and health, noise, and cultural pollution are among the most visible ones. Sprawling, litter, and polluted waterways are most prevalent in most urban slums. The areas are with basic urban service and infrastructure deficits, urban planning, and management deficiencies, affecting the city's livability and environmental quality. They are located on marginal land that is exposed to the risk of storms, fire, disease, and flooding (Mohanty 2005). They are critically vulnerable or susceptible to various economic as well as environmental risks.

The "squatter citizens" face numerous challenges in their struggle for survival in cities (Hardoy and Satterthwaite 1989). The informal settlement areas become a huge challenge as the areas are not legalized where building plans can be approved and implemented. Civic authorities have no choice but to demolish these buildings that lead to social chaos, and the issue very often becomes politicized. In addition, informal settlement dwellers also take illegal water and electricity connections and do not adhere to the city regulations, which often remain a challenge to sustainable urban planning.

The civic authorities face with serious urban planning and management challenges by the presence of squatter settlements and slums. Forced evictions adopted by several governments in various parts of the world put the rights of squatter dwellers at risk and lead to violation of human rights. The challenges are to provide effective protection against forced evictions and to provide access to basic services, public facilities, and inclusive public spaces to the evicted/displaced dwellers. There are significant challenges faced by urban planners in achieving slum and urban upgrading. The informal settlements are heterogeneous entities and include urban dwellers with varied needs and interests. The primary challenges in upgrading informal settlements are achieving some kind of coherence in the community and finding solutions to a wide range of needs and interests. The best way to do this is through negotiated development, in which people participate in negotiating their rights. Amao (2012) noted that insufficient financial and human resources, burdensome regulatory rules, unclear administrative procedures, and unrealistic standards have been the major challenges to successful upgrading. Upgrading of informal settlements is part of the housing programs, which aims to address the housing challenges. Responses to the housing question often remain very technical and developmental in nature. A lack of coordination between housing and other urban services and infrastructure agencies are very often the challenges to successful upgrading.

The informal settlements are upgraded incrementally on the same site. Incremental housing is a step-by-step process of upgrading informal settlements. Incrementalism allows informal housing to be adapted over time. There is a need to develop 
the incremental settlement process in such a manner that it will lead to access to integrated human settlements. The process has multiple stakeholders and requires active participation of urban citizen in the process. The informal settlement praxis is cross-border in nature, and thus, the process toward incremental upgrading, the complexities, and dynamism is universal. The increasing rate of urbanization especially informal urbanization and settlements is a great challenge, and upgrading informal settlements to well-serviced and integrated neighborhoods poses a daunting challenge.

A lack of recognition by relevant government authorities of the urban informal settlements as part of urban fabric is a major impediment to improve the living conditions of these settlements. As a result, the informal settlements have not received adequate developmental attention. Other challenges that slum upgrading programs face as Ndukui (2013) noted are complexities of slum settlements with regard to tenure arrangements, lack of coordination of various stakeholders, resistance to the slum upgrading program especially by the slumlords, lack of participation by the slum dwellers in the upgrading program, residents not being aware of their roles as stakeholders in the upgrading program, lack of adequate land for slum upgrading, lack of goodwill and mistrust from the slum dwellers, inadequate budgetary allocations to the program from the government, and above all the politicization of the upgrading program. Another daunting issue in informal settlement planning is lack of reliable data. Information on demographic, social, and economic characteristics of people living in informal settlements is often limited, as this information is not generally captured in official national censuses. A comprehensive knowledge about informal settlements is needed to plan for improving housing, quality of life, and environment in cities. Both the United Nations and the World Bank consider the best practice for dealing with slums challenges is to be participatory slum improvement (UN-Habitat 2003).

\section{Squatter Settlements and Slums and Sustainable Development}

Squatter settlements and slums in cities and urban environmental unsustainability are closely intertwined. The squatter settlements and slums are major challenges to urban planning and sustainable development due to their complex social, economic, and environmental implications. They define the urban economy, spatial growth, and evolution of many cities in developing countries (Pugh 2000a, b; Neuwirth 2005). They are the real threats to achieve urban sustainability and sustainable urban development. They pose a serious threat to the local and national governments and urban governance and put challenges for spatial planning and urban design. Improving the lives of squatter dwellers in cities and towns is one of the most pressing developmental challenges. The main challenge is how to integrate informal settlements and informal urban development into a formal system. The greatest challenge remains how to build sustainable or healthy cities and communities. With the publication of Urban Future 21: A Global Agenda for Twenty-First Century, Hall and Pfeiffer (2000) said cities have to be livable and with a "decent home for every citizen, a built environment rich in urban design, with good quality services, easy access, varied land use, cultural complexity, diversity, and the right mixture of vibrancy and tranquility."

Squatter settlements and slums can contribute to social, cultural, economic, and environmental sustainability and sustainable development through their economic resources, cultural capital, people's belongingness, and participative processes in informal city (Dreifuss-Serrano 2015; Guibrunet and Broto 2015). Informal settlements are sustainable when they cope with stresses and shocks, and this can happen by enhancing their capabilities and assets. Squatter settlements and slum upgrading are widely recognized for empowering the squatter and slum dwellers, enhancing shelter and promoting economic development. Slum upgrading denotes initiatives seeking to improve housing quality, infrastructure provision, social services, livelihoods, and official recognition of residents. Slum upgrading is also a 
process that meaningfully includes the urban poor in project design and implementation and aims to integrate slums into the larger fabric of the city. Slum upgrading is a "curative" approach - a necessary but not a sufficient condition, slum prevention is equally important (World Bank 2015). It is also equally important to build local partnership with sub-national governments, communities, and the private sector to work toward enhancing access, opportunities, and rights of all, in order to achieve an inclusive development in urban areas (World Bank 2015), a prerequisite to achieve sustainable development. The role of NGOs and civil society is essential in creating inclusive cities and building sustainable communities through their ability to work directly with communities.

\section{Way Forward}

Urbanization is expected to grow unprecedentedly especially in the developing countries. Informal settlements are likely to grow with growing urbanization. Gouvernuer's (2015) in his work Planning and Design for Future Informal Settlements: Shaping the Self-Constructed City focused on a realistic approach that recognizes the current urban realities in developing countries, and it provided useful tips for future planning and design of informal settlements rather than eliminating these settlements (cited in Mohanty 2019). Gouvernuer (2015) relies on a strategy for "guiding the growth of emerging informal settlements, anticipating that properly self-constructed cities can become balanced, efficient, accessible, and desirable urban areas." According to Gouvernuer (2015), "developed Informal Armateurs (IA) which is a design and managerial approach that fosters sustainable growth of the informal city...enhancing their positive aspects while addressing their deficiencies." The Informal Armateurs is easy to implement design and managerial approach with the ability to provide residents with conditions that they can achieve themselves. Okyere (2016) suggests that merging planning, design, and management solutions is a way forward for the future of the informal city. A comprehensive approach to upgrading slums needs to be seen as a way to foster equitable and inclusive development (Hermanson 2016). "Informal settlements can be both catalyst and vehicle for the achievement of greater inclusiveness while fostering innovation, creating jobs and developing social capital" (ibid.). Forced eviction of slum or squatter dwellers to the periphery will not solve the problem. The understanding of the dynamics and complexities around informal settlements needs to be rationalized. Ooi and Phua (2007) emphasized, the city governments need to establish the link between economic development, urban growth, and housing. Urban planning toward the informal city should be formulated from a broader policy of social housing and not be encapsulated in slum upgrading and regularization programs, as straightforward outcomes of informality (Cockburn 2014). The approaches of "self-help" and "popular participation" are to be integrated in urban community program where the squatter and slum dwellers can play a greater role.

\section{Conclusions}

Informal urbanization and urban informality is a developmental challenge and threat to sustainability and sustainable development. Squatter settlements and slums are linked to broader issues of marginalization, poverty, inequality, exclusion, and urban planning and governance. Informal settlement upgrading is a developmental process that needs to be a part of the broader human settlement delivery framework. There is a greater need to integrate urban design into upgrading of informal settlements and also a need to adopt integrated approach to planning and management of informal urbanization. Squatter settlements and slum upgrading are widely recognized for empowering the squatter and slum dwellers, providing enhanced shelter, and promoting city development. Community participation from informal settlements is vital in the process of urban upgrading. Multidisciplinary and structured approaches are essential to tackle the challenges of informal settlements in cities. Informal 
settlements hold much promise for achieving more "inclusive" and sustainable cities. If planned and developed properly, informal settlements could help in achieving more socially just and "sustainable" cities. Squatter settlements and slums need to be seen as solutions rather than problems to city planning and in converting informal urbanization to formal system. Interventions and cooperations from government, nongovernmental organization and civil society, private bodies, and communities are most needed (Mitlin and Satterthwaite 2004) to make slum upgrading, in particular, and urban planning and development, in general, successful in building sustainable communities and "livable" cities.

\section{Cross-References}

\author{
- Challenges of Informal Urbanization \\ $\checkmark$ Housing Policies \\ - Inclusive City \\ - Poverty Reduction Strategies \\ - Sustainable Urban Planning
}

\section{References}

Abbott J (2002) An analysis of informal settlement upgrading and critique of existing methodological approaches. Habitat Int 26(3):303-315

Abrams C (1964) Man's struggle for shelter in an urbanized world. MIT Press, Cambridge

Acioly C (2007) The challenge of slum formation in the developing world, land lines. Lincoln Institute of Land Policy, Cambridge

Amao FL (2012) Housing quality in informal settlements and urban upgrading in Ibadan, Nigeria. Dev Ctry Stud 2(10):68-80

Amis P (1984) Squatters or tenants: the commercialization of unauthorized housing in Nairobi. World Dev 12 (1):87-96

Beard DC (1920) Shelters, shacks and shanties. University of Virginia: Charles Scribner's Sons, New York

Bellegooijen JV, Rocco R (2013) The ideologies of informality: informal urbanization in the architectural and planning discourses. Third World Q 34(10):1794-1810

Bowles S, Durlauf S, Hoff K (2011) Poverty trap. https://www.researchgate.net/publication/291935857_ Poverty_traps. Accessed 5 Sept 2019

Bunnel T, Harris A (2012) Reviewing informality: perspectives from Asia. Int Dev Plan Rev 34(4):339-347
Carroll A (2002) Lesson learned on urban upgrading. UNHabitat, World Urban Forum, Nairobi

Cities Alliance (2016) Cities without slums. Cities Alliance. http://www.citiesalliance.org/About-slum upgrading\#Why_is_slum_upgrading_important.

Accessed 9 May 2016

Cockburn JC (2014) Lessons from the ground up: approaches to squatter settlements. Working paper. Lincoln Institute of Land Policy. https://www. lincolninst.edu/sites/default/files/pubfiles/2446_1792_ calderon_wp14jc4.pdf. Accessed 28 Aug 2019

Davis M (2006) Planet of slums. Verso, London

De Soto H (1989) The other path: the invisible revolution in the Third World. I. B. Taurus, London

Dovey K, King R (2011) Forms of informality: morphology and visibility of informal settlements. Built Environ 37(1):11-29

Dreifuss-Serrano C (2015) Sustainability through informality. Eur J Sustain Dev 4(2):1-8

Eckstein S (1990) Urbanization revisited: inner-city slum of hope and squatter settlement of despair. World Dev 18(2):165-181

Ehebrecht D (2015) The challenge of informal settlement upgrading: breaking new ground in Hangberg, Cape Town? Universitatsverlag Potsdam, Potsdam

Evans P (ed) (2002) Livable cities? Struggles for livelihood and sustainability. University of California Press, Berkeley

Fox S (2013) The political economy of slums: theory and evidence from sub-Saharan Africa. World Dev 54:191-203

Frankenhoff CA (1967) Elements of an economic model for slums in a developing economy. Econ Dev Cult Chang 16(1):27-36

Global Urban Observatory (2003) Slums of the world: the face of urban poverty in the new millennium. United Nations Habitat working paper. United Nations Habitat. https://unhabitat.org/wp-content/ uploads/2003/07/GRHS 2003_Chapter_01_Revised 2010.pdf. Accessed 26 Aug 2019

Gouvernuer D (2015) Planning and design for future informal settlements: shaping the self-constructed city. Routledge, London

Guibrunet L, Broto CV (2015) The sustainability of the informal city: an urban metabolism approach. http://www.esee2015.org/wp-content/uploads/2015/ 10/0220.pdf. Accessed 26 Aug 2019

Hall P, Pfeiffer U (2000) Urban future 21: a global agenda for 21 st century cities. E \& FN Spon, London

Hardoy JE, Satterthwaite D (1989) Squatter citizen: life in the urban Third World. Earthscan, London

Hermanson JA (2016) Achieving inclusiveness: the challenge and potential of informal settlements. Habitat III. http://citiscope.org/habitatIII/commentary/2016/01/ achieving-inclusiveness-challenge-and-potential-infor mal-settlements. Accessed 29 May 2018

Hernandez F, Kellett P, Allen L (eds) (2012) Rethinking the informal city: critical perspectives from Latin America. Berghahn Books, New York 
Huchzermeyer M, Karam A (eds) (2007) Informal settlements: a perpetual challenge? CPT Press, Cape Town

Lombard M (2014) Constructing ordinary places: place making in urban informal settlements in Mexico. Prog Plan 94:1-53

Mitlin D, Satterthwaite D (2004) Empowering squatter citizen: local government, civil society and urban poverty reduction. Earthscan, London

Mohanty M (2005) Poverty, environmental hazards and vulnerability of urban poor in small island states: a case of squatter communities in Suva city, Fiji Islands. In: Feng FH, Yu L, Solecki W (eds) Urban dimensions of environmental change: science, exposures, policies and technologies. Science Press, Monmouth Junction, pp 231-236

Mohanty M (2006) Urban squatters, the informal sector and livelihood strategies of the poor in Fiji Islands. Dev Bull 70:65-68

Mohanty M (2019) Challenges of informal urbanization. In: Filho WL et al (eds) Sustainable cities and communities, encyclopedia of the UN Sustainable Development Goals. Springer Nature, Cham, pp 1-11. 978-3-319-71061-8

Ndukui CE (2013) Challenges of slum upgrading for urban informal settlements: case of Soweto East Village in Kibera informal settlements, City of Nairobi. University of Nairobi, Nairobi

Neuwirth R (2004) Shadow cities: a billion squatters in a new urban world. Routledge, Abingdon

Neuwirth R (2005) How shanty towns become real cities. Fortune 152(8):59-62

Obudho RA, Mhlanga CC (eds) (1988) Slum and squatter settlements in sub-Saharan Africa: toward a planning strategy. Praeger, New York

Okyere DSA (2016) The future of the informal city: merging planning, design and management solutions. Division of Global Architecture, Osaka University, Osaka. http://www.urbanisticatre.uniroma3.it/dipsu/? portfolio $=\mathrm{a}$-future-for-the-informal-city

Ooi G, Phua K (2007) Urbanization and slum formation. J Urban Health 84:27-34

Pamuk A, Cavallieri PFA (1998) Alleviating urban poverty in a global city: new trends in upgrading Riode-Janeiro's favelas. Habitat Int 22(4):449-462

Perlman J (1976) The myth of marginality. University of California Press, Berkeley

Porter L (2011) Informality, the commons and the paradoxes for planning: concepts and debates for informality and planning. Plan Theory Pract 12(1):115-153

Pruijt H (2011) Logic of urban squatting. Int J Urban Reg Res 37(1):1-8

Pugh C (1997) Poverty and progress? Reflections on housing and urban policies in developing countries, 1976-96. Urban Stud 34(10):112-129

Pugh C (2000a) Squatter settlements: their sustainability, architectural contributions, and socio-economic roles. Cities 17(5):325-337
Pugh C (2000b) Sustainability of squatter settlements. In: Pugh C (ed) Sustainable cities in developing countries. Earthscan, London, pp 135-151

Pyne GK (1977) Urban housing in the Third World. Leonard Hill, London

Ravallion M, Chen S, Sangraula P (2007) The urbanization of global poverty. World Bank. http://siteresources. worldbank.org/INTDECINEQ/Resources/Urbanizatio npoverty.pdf. Accessed 5 Sept 2019

Rocco R, Bellegooijen JV (2018) The Routledge handbook on informal urbanization. Routledge, London/New York

Roy A (2005) Urban informality: towards an epistemology of planning. J Am Plan Assoc 71(2):147-158

Sietchiping R (2005) Prospective slum policies: conceptualization and implementation of a proposed informal settlement growth model. https://pdfs.semanticscholar. org/948f/1 acf79ba85df2173142fa8063123d45dd6a4. pdf. Accessed 30 Aug 2019

Skinner RJ, Rodell MJ (eds) (1983) People, poverty and shelter: problems of self-help housing in the Third World. Methuen, London

Srinivas H (2015) Squatting: defining squatter settlements. http://www.gdrc.org/uem/define-squatter.html.

Accessed 29 Aug 2019

Turner JFC (1969) Uncontrolled urban settlement: problems and policies. In: Breese G (ed) The city in newly developing countries: readings on urbanism and urbanization. Prentice Hall, Englewood Cliffs, pp 507-534

Turok I, Borel-Saladin J (2016) The theory and reality of urban slums: pathways-out-of-poverty or cul-de-sacs? Urban Stud 55(4):767-789. http://journals.sagepub. com/doi/abs/10.1177/0042098016671109. Accessed 28 Aug 2019

UH-Habitat (2010) The challenge of slums: global report on human settlements 2003 - revised version. UNHabitat, London/Sterling

UN-Habitat (2003) The challenge of slums. Global report on human settlements. Earthscan, London

UN-Habitat (2006) The state of the world's cities report 2006/2007: the millennium development goals and urban sustainability. United Nations Human Settlements Program, Nairobi

UN-Habitat (2008) State of the world's cities 2010/2011: bridging the urban divide. Earthscan, London

United Nations (2013) Sustainable Development Goals. $\mathrm{http} / /$ www.unfoundation.org/features/globalgoals/theglobal-goals.html. Accessed 26 Aug 2019

Ward D (1976) The Victorian slum: an enduring myth? Ann Assoc Am Geogr 66(2):323-336

Werlin H (1999) The slum upgrading myth. Urban Stud 36:1523-1534

World Bank (2015) World inclusive cities approach paper. Report no AUS8539. http://www-wds.wordbank.org. Accessed 25 Aug 2019 